Article

\title{
Issues of Corrosion and Degradation under Dusty Deposits of Energy Biomass
}

\author{
Milena Bojanowska ${ }^{1, *(\mathbb{C}}$, Jarosław Chmiel ${ }^{1} \oplus$, Maria Sozańska ${ }^{2}{ }^{\oplus}$, Bartosz Chmiela ${ }^{2}$, Joanna Grudzień ${ }^{1}$ and \\ Justyna Halska ${ }^{1}$ (D) \\ 1 Faculty of Transport Engineering and Economics, Maritime University of Szczecin, ul. \\ Henryka Pobożnego 11, 70-507 Szczecin, Poland; j.chmiel@am.szczecin.pl (J.C.); joanna_grudzien@o2.pl (J.G.); \\ justyna.halska@wp.pl (J.H.) \\ 2 Faculty of Materials Engineering and Metallurgy, Silesian University of Technology, ul. Krasińskiego 8, 40-019 \\ Katowice, Poland; maria.sozanska@polsl.pl (M.S.); bartosz.chmiela@polsl.pl (B.C.) \\ * Correspondence: m.bojanowska@am.szczecin.pl
}

check for

updates

Citation: Bojanowska, M.; Chmiel, J.; Sozańska, M.; Chmiela, B.; Grudzień, J.; Halska, J. Issues of Corrosion and Degradation under Dusty Deposits of Energy Biomass. Energies 2021, 14, 534. https://doi.org/10.3390/ en14030534

Received: 2 December 2020

Accepted: 19 January 2021

Published: 21 January 2021

Publisher's Note: MDPI stays neutral with regard to jurisdictional claims in published maps and institutional affiliations.

Copyright: (c) 2021 by the authors. Licensee MDPI, Basel, Switzerland. This article is an open access article distributed under the terms and conditions of the Creative Commons Attribution (CC BY) license (https:/ / creativecommons.org/licenses/by/ $4.0 /)$.

\begin{abstract}
The aim of the study is to identify and determine the role of microbial degradation taking place in dusty deposits in potential threats (i.e., destruction of protective coatings and development of corrosion) to the means of transport in conditions of transshipment of energy biomass. This paper presents the results of research on the impact of powdery fractions of wood biomass and biomass obtained from oil plants in the degradation of paint coatings and corrosion processes. During the research, exposure to simulated port climate, OM, SEM, and EDS studies were used. It has been found that the presence of the fraction containing protein compounds and amino acids (e.g., dust of rapeseed meal) stimulates the growth of microorganisms whose metabolism products favour the destruction of protective coatings and the development of corrosion. Under the same conditions, the destruction of protective zinc coatings has been observed. It was found that already 14 days of exposure to oily biomass deposits results in damage to paint coatings caused by microbiological processes. The 8-week exposure causes serious degradation of protective coatings and the base material itself. The biomass of wood origin, containing compounds of the tannin type, did not show as much aggressive activity as the biomass with protein compounds.
\end{abstract}

Keywords: energy biomass; corrosion; microbial corrosion; degradation of coatings; hydrogen degradation; maintenance management

\section{Introduction}

The global seaborne trade of bulk cargoes has been systematically increasing for several years, approaching the volume of 2900 million tons in main bulk commodities: Iron ore, coal, grain, bauxite, alumina, and phosphate rock. In dry cargoes other than main bulk commodities, an upward trend from 3100 to 4200 million tons has been observed since 2013 [1]. Detailed data on selected cargo classes are presented, among others, in publications [2-4]. Rapeseed is the second most important, after soya beans, for the vegetable oil industry, with an annual production volume of more than 70 million tons [2]. The annual world production of oilseeds meals (soybean, rapeseed, sunflower, cotton, copra, peanuts, and palm oil) is now more than 290 million tons [2].

The basic problem in handling bulk cargoes is the presence of powdery fractions and the associated dust environment. The problem of dust in sea ports mainly refers to cargoes such as coal, metal ores, and chemical products [5]. Most attention is paid to the problems of dust and its impact on the environment (including explosiveness) or physiology and health [6-12].

Hazardous effects of dust are also observed when handling the bulk of vegetable origin, in particular of crushed seeds. Creation of dust-air suspension and formation of layers of deposits on surfaces of machinery parts (Figure 1) may result in the participation of powdery 
fraction in varied forms of wear and destruction of infrastructure: From erosion of tribological nodes in machinery through development of corrosion processes to the total destruction of the object as a result of the explosion of a dust-air mixture [5,13-17]. The identification of chemical hazards related to changes in plant-derived cargoes is presented in the paper [18] and the impact on transport facilities elements is shown in the works $[5,19,20]$.

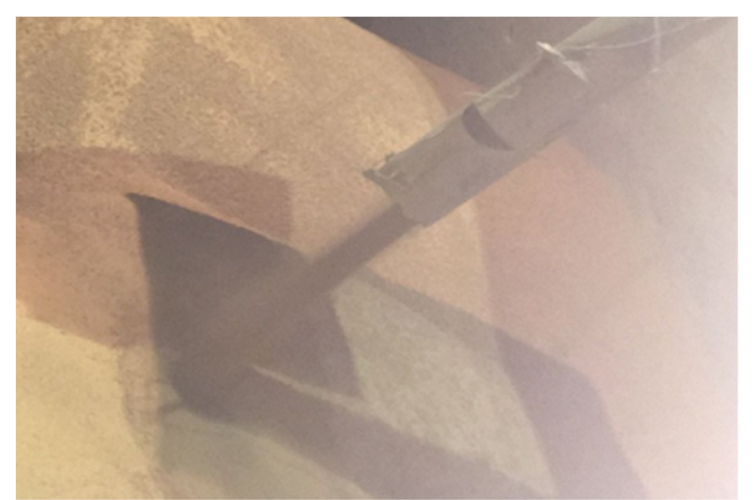

(a)

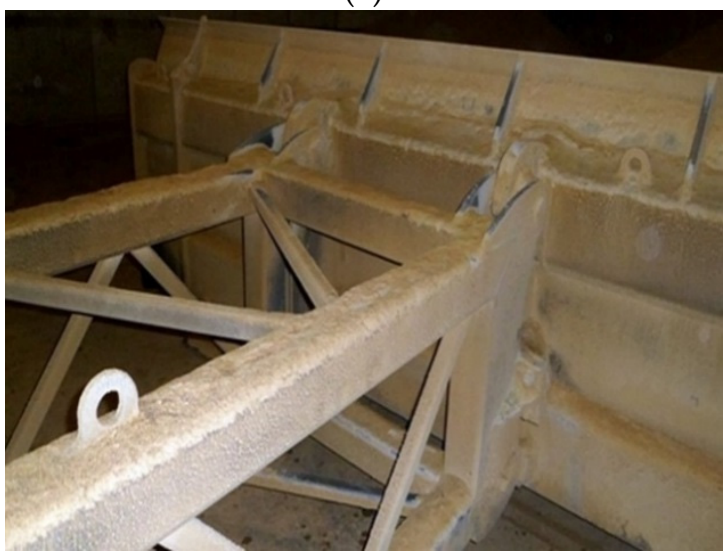

(c)

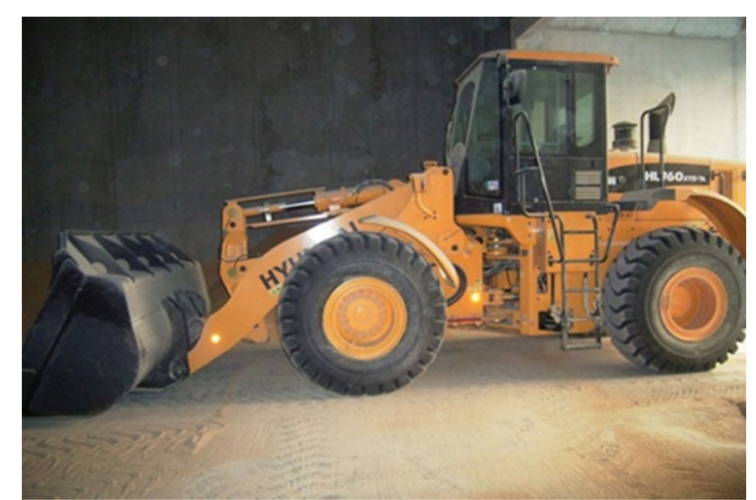

(b)

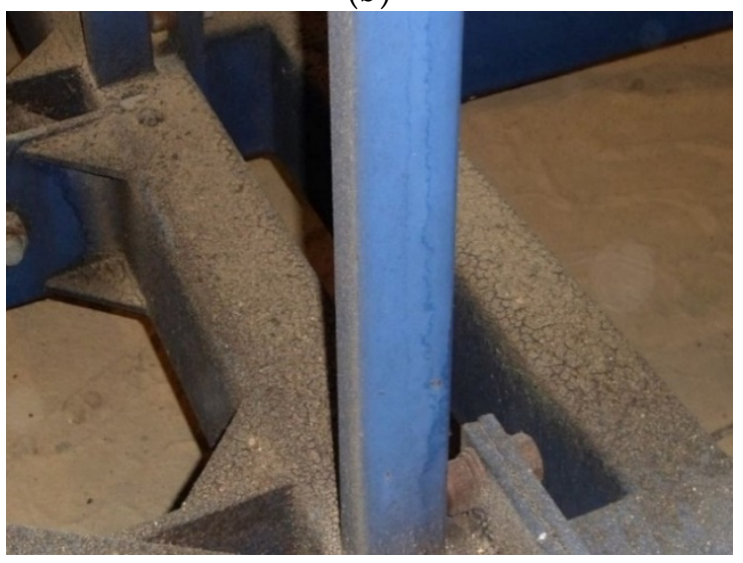

(d)

Figure 1. Examples of emission (a) and deposition of powdery fraction of seed meal on the floor of a warehouse (b) and machinery parts (c,d) (original photos by J. Chmiel, J. Halska).

A relatively new category of bulk cargo-waste fractions of products of plant originare used as energy biomass. The term energy biomass is to be understood as: (a) Raw materials for the production of liquid fuels or components: Bioalcohol and biodiesel; (b) raw materials for briquetting and pelleting, or (c) dry biomass for combustion or co-firing in power-plant boilers.

In contrast to plant products for food and fodder use [21-23], biomass does not undergo several types of treatment to prevent qualitative changes in transport and is not subject to restrictive testing of quality parameters relevant to the consumer. For example, the basic parameters of biomass for the purpose of (b) and (c) are the calorific value, moisture, and ash content [24]. Energy biomass is not classified and identified as a separate statistical category of cargoes, but based on the data presented in [1] its share can be estimated at several hundred million tons.

The motivation for studies of the effects of dust fractions on the development of damage to the cargo handling equipment are: The mass character of transport processes; known vulnerability of vegetable origin cargoes to biological and chemical processes leading to their degradation, and known occurrence of corrosion phenomena with a microbiological basis on technical facilities in ports. The share of dusty fractions for the exemplary agricultural biomass-rapeseed meal $(\mathrm{d}<0.4 \mathrm{~mm})$ reaches $25 \%(\mathrm{~m} / \mathrm{m})$. During handling of 5 thousand tons of rapeseed meal in relation to the warehouse-ship, 
about 5 tons of dust with particle size $<0.075 \mathrm{~mm}$, and 290 tons of particulates in the size range of $0.075-0.2 \mathrm{~mm}$ are moved.

The vast majority of publications on the corrosive influence of biomass concerns the high temperature corrosion of boilers under combustion conditions above $550{ }^{\circ} \mathrm{C}$. The described corrosion processes are related to the activity of potassium and other alkaline metal compounds $[25,26]$ or the presence and activity of fly ash deposits, specific for biomass co-firing $[27,28]$. Moreover, a number of publications concern surface layers resistant to specific conditions of energy biomass combustion, e.g., [29,30].

Biomass containing oily and protein fractions shows corrosive activity towards construction materials in low temperatures. This applies to both unalloyed and low-alloyed structural steels [31] and acid-resistant steels Cr-Ni 18-9 grade [32]. In the latter case, an important role of sulfur compounds, present in rape seeds, in the development of corrosion and tribocorrosion damages is indicated [32].

The microbiological corrosion of metal materials is described in a number of publications, which indicate a very important role of sulfur-reducing bacteria and bacteria causing environmental acidification [33-36]. Such an effect favors both typical corrosion processes and hydrogen degradation processes. In turn, the publication [37] points out the dualism of the bacterial film's influence. Specific bacterial strains can then act as corrosion inhibitors.

The variety of processes presented in the above publications indicate the interdisciplinary nature of the issue of biomass impact on construction materials. In contrast to food and fodder products, waste biomass for energy purposes may show heterogeneous composition and, for economical reasons, may not be disinfected and treated with fungicides.

The aim of the study is to identify and determine the role of processes taking place in dusty deposits in potential threats (i.e., destruction of protective coatings and development of corrosion) to the means of transport in conditions of transshipment of energy biomass in sea ports and power plants located on harbor areas. Chemical, electrochemical, and physical processes that may occur in the presence of microbiological phenomena are considered as potential sources of danger. The cooperation with harbor and energy operators indicate that the problem of corrosive impact of energy biomass deposits, especially oily ones, in the port microclimate is underestimated by users.

The presented research works are part of a long-term project "Interactions and feedback between cargo and means of transport", carried out at the Faculty of Transport Engineering and Economics of Maritime University of Szczecin. The primary goal of the entire program, including this publication, is to provide knowledge about complex interdisciplinary interactive processes. The literature on such processes is usually scattered, hence, the attempt to present the phenomena in one publication. Due to the specificity of the operation of power plants and combined heat and power plants using energy biomass, located in port areas and in the generally understood coastal zone, the publication is addressed mainly to specialists related to the operation of such facilities.

The assumptions of the experiment were based on the exposition of a typical constrictive material with standard corrosion protection under conditions typical of a port microclimate in a temperate climate zone during the summer season and were presented in Section 2. The results of model tests and their discussion are presented in Section 3 , including visual inspection (Section 3.1), determination of microbial colony growth model (Section 3.2), visible light microscopic evaluation (Section 3.3) and SEM and EDS microanalysis (Section 3.4). The conclusions are presented in Section 4.

\section{Materials and Methods}

Metallic $50 \times 50 \times 1.5 \mathrm{~mm}$ specimens were prepared from low-carbon steel in the form of plates. Two types of corrosion protection were used [38,39]. The first variant of protection embraced a two-layer paint coating, based on chlorinated rubber paint which included one layer of undercoat (red ferro oxide) and one layer of topcoat chlorinated rubber paint (RAL 6001 green). In the second variant of the experiment, a combined protection was used: Zinc layer and single layer paint coating chlorinated rubber paint 
(RAL 6001 green). Both paints used in the experiment came from one product line of the same manufacturer. The choice of paints based on rubber chlorine was determined by the known high chemical and abrasive resistance of these materials.

The first layer of paint was applied to the cleaned and degreased surface using a paint roller. The hardening time of each layer was arbitrarily set as $24 \mathrm{~h}$. After the primer paint layer dried up, a top coat was applied. In the case of the zinc coating paint, the top coat was applied directly on the zinc ground. The thickness of the zinc and paint layer was controlled by a Sauter TC-1250-0.1F (Sauter GmbH, Balingen, Germany)thickness gauge and amounted to: $12 \pm 4 \mu \mathrm{m}$ for the zinc layer; $48 \pm 12 \mu \mathrm{m}$ for the undercoat, and $52 \pm 15 \mu \mathrm{m}$ for the topcoat.

After complete drying, an intentional damage of protective coatings was made using a steel blade with an angle of $60^{\circ}$ down to the steel surface.

Two types of biomass dust models were used: (1) Waste fractions of rapeseed meal dust after the extraction process, not treated by fungicides; (2) waste mixed wood dust, derived from carpentry plant, having an approximate composition of pine, oak, and beech in 1:1:1 proportion. The choice as a model oily biomass resulted from the existence of comparative data on the corrosive impact of this product $[32,40]$, while the biomass from wood waste currently represents the most often used solid biofuel in Poland. The biomass dust layer was applied by shaking the sieve with a mesh size of $0.2 \mathrm{~mm}$ from a height of $5 \mathrm{~cm}$ onto the surface of the sample to obtain a thickness of approx. $1 \mathrm{~mm}$ (Figure 2). The rapeseed meal dust used in the study was a high-protein fraction containing: $43.4 \%$ of crude protein, $7.8 \%$ of fiber, $5.1 \%$ of oil, and $6.4 \%$ of ash in dry matter, according to own measurements (the NIRS method, FT-NIR MPA-Multi Purpose Analyzer, Bruker Optics; Billerica, MA, USA). The remaining 37.3\% dm of rapeseed meal dust are nitrogen-free compounds, mainly carbohydrates.

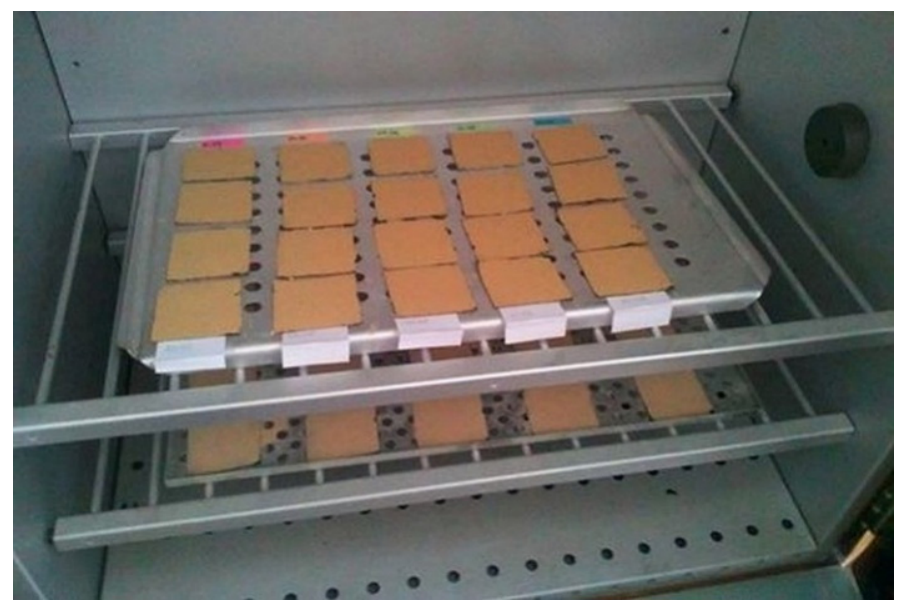

Figure 2. Specimens with a layer of biomass in a climate chamber.

The prepared specimens in a climate chamber were exposed for 10 weeks to ambient air temperature of $30{ }^{\circ} \mathrm{C}$ and relative humidity of $60 \%$. These conditions were based on the data obtained in the port of Szczecin, taking into account the summer season and the location of handling equipment.

Every 2 weeks, five samples were selected and subjected to the following tests: (1) Visual inspection of the surface with a biomass layer and after its removal and photographics documentation of the overviews, using a DSLR camera Canon 300D with 15-55 mm lens (Canon Inc., Tokyo, Japan); (2) measurement of areas where changes were observed, using the digital image processing software (ImageJ, https://imagej.nih.gov/ij); (3) observations of enlarged specimens, up to $50 \times$ (Zeiss Stemi microscope with an Axiocam 105 camera and Zeiss Zen Core software, Carl Zeiss Microscopy GmbH, Jena, Germany); (4) microstructural SEM investigations using a Hitachi S-3400N scanning electron microscope 
(Hitachi High-Tech Corporation, Tokyo, Japan) with a Thermo Noran energy dispersive X-ray spectrometer (EDS) Thermo Fisher Scientific, Waltham, MA USA.

\section{Results and Discussion}

\subsection{Visual Inspection of Biomass Layer}

Specimens exposed in the climate chamber were subjected to visual observations every 14 days. It was found that after 14 days, changes in the color and structure of the dusty layer were already visible on the surface of the biomass layer derived from oil plants. Such changes were not observed on the surface of wood biomass sediment. A comparison of visual observations with the results available in the literature allows identifying discolored areas as zones where colonies of microorganisms specific for oil plants developed (Figure 3) [39]. It was found that the highest growth intensity of the areas identified as infected by microorganisms occurs on the samples painted twice, with a layer of oil biomass. A slightly lower intensity occurs on the samples with zinc coating as the base. Under the experimental conditions, no microbial colonies incubation nor growth was observed in the layers of sediments of wood origin [38]. Comparing the two groups of biomass chosen in the experimental part, generally the woody residues have a lower nitrogen and ash content than agricultural wastes and are rich in cellulose, hemicellulose, and lignin components. The nitrogen content of woody biomass is about $0.1-0.75 \%$, while in agricultural biomass, such as rapeseed meal, its content can reach $6.4 \%$. Woody dust has practically no sulfur at all, as its share does not exceed $0.05 \%$. In agricultural dust, the concentration of sulfur is usually higher than $0.5 \%$. In the case of rapeseed meal, its content amounts to $1 \%$ [41,42].

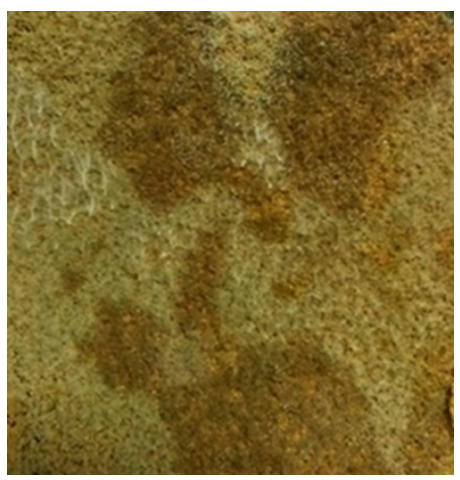

(a)

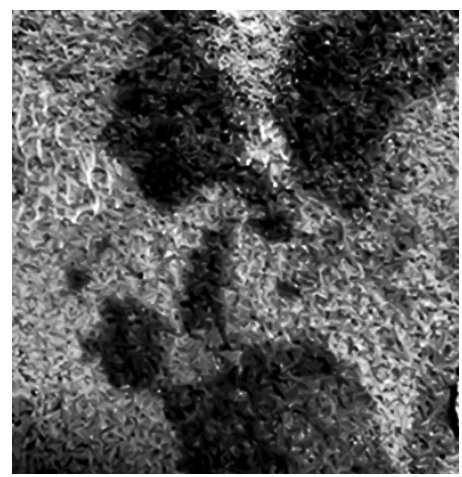

(b)

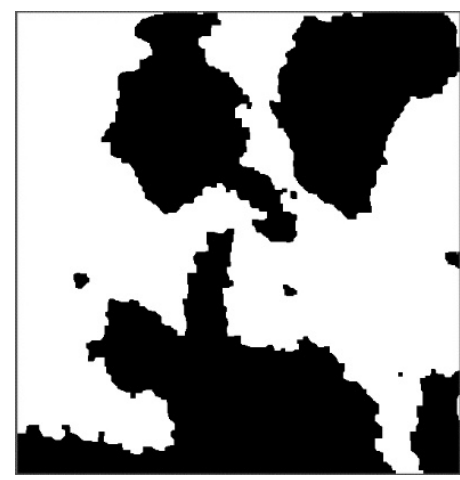

(c)

Figure 3. A specimen after 4 weeks: (a) Source image $40 \times 40 \mathrm{~mm}$; (b) monochromatic image before segmentation; (c) binary image, area of colonies: $44 \%$ of specimen.

The generalization of these observations makes it possible to conclude that two basic models of the influence of biomass sediment layers on corrosive processes can be indicated:

(a) Non-corrosive layers such as biomass of wood origin and dusts of plant products for food and feed use (fumigated with antibacterial and fungicides);

(b) Corrosive active layers such as powder of waste biomass for energy purposes, which is not subject to treatment with fungicides and antibacterial agents and does not have to comply with restrictions related to the stability of biochemical properties. This group includes, among others, waste fractions of oil plants.

\subsection{Quantitative Description of Colonies Growth}

Surface images of the specimens with powdery layers were subjected to image processing and planimetry of the areas identified as infested with microorganisms (Figure 3). The percentage shares of the affected area are shown in Figure 4. 

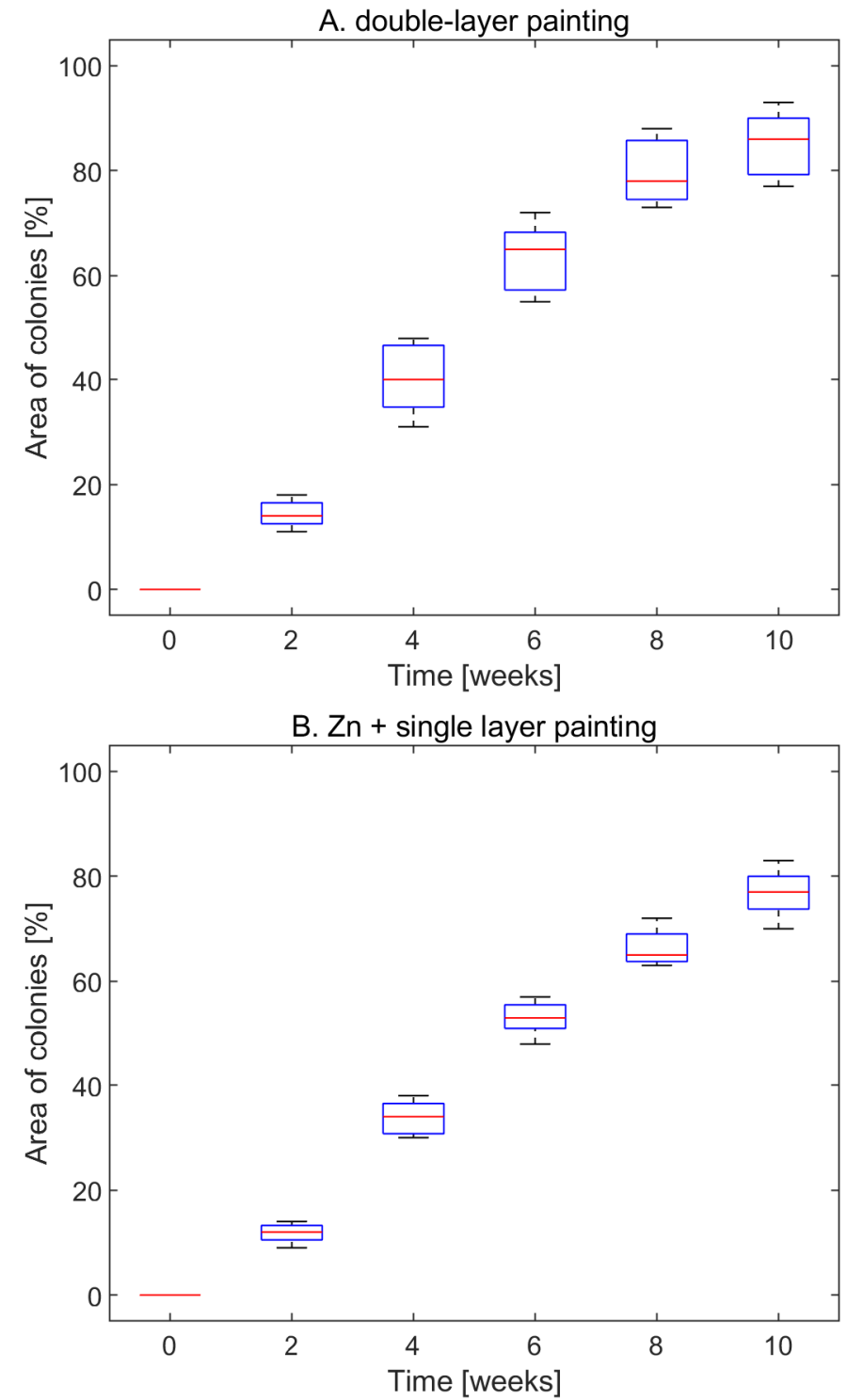

Figure 4. Percentage of areas with changes in the biomass layer. (A) Double-layer coating, (B) zincpaint coating.

The growth rate of areas being attacked by microflora $A(t)$ was approximated in the MATLAB software by a logistic model (Equation (1)):

$$
A(t)=\frac{D}{1+C \cdot \mathrm{e}^{-B \cdot t}}
$$

The choice of the simplest logistic model results from the variability of actual operating conditions and diversity of conditions of the performed corrosion experiment from the conditions of typically microbiological experiments. This second class of experiments is carried out under conditions of bacterial monocultures cultivated on appropriate media and more complex mathematical models of colony growth can be used, e.g., Gompertz, Conline, Ratkowsky, Huang, or other functions [43-47]. The estimation results for oilseedorigin biomass samples are shown in Figure 5. For Equation (1) and Neldner-Mead algorithm matching (fminsearch command), the values of the terms D, C, B were obtained $85.8233,20.3899,0.6978$ (for the double layer coating) and 82.4582, 19.4839, 0.7152 (for the Zn-paint), respectively. 


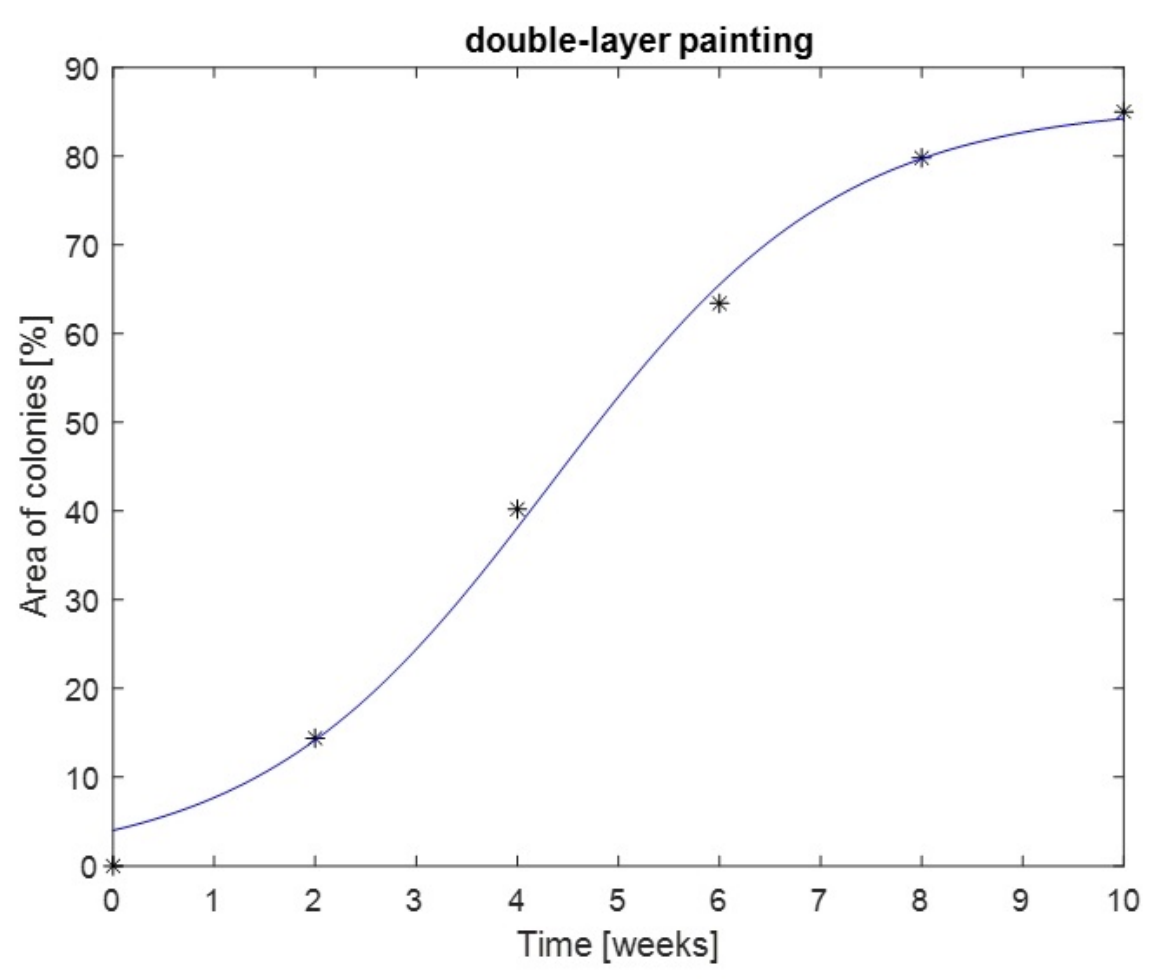

Figure 5. Approximation of colonies growth with a logistics curve for the double-layer paint coating.

\subsection{Macroscopic and Microscopic Examination of Specimens}

After removing the biomass layer, the samples were subjected to macroscopic and microscopic observations. Three characteristic types of damage development were found. In the specimens with a layer of oily biomass on the substrate of two layers of paint, intensive degradation affected the paint film under the areas of biomass attacked by microorganisms. This degradation was visible as a clear discoloration of the topcoat (Figure 6a). Two classes of processes were considered as potential causes of this form of protective coating degradation: (1) Direct physical impact of oily fractions on the base and pigments of the coating and (2) possible effects of microbiological processes. The chemical composition of the biomass used in the experiment, previous studies [48,49], and literature data $[50,51]$ indicate a decisive contribution of the microbiological factor to the development of this form of destruction. Previous studies on the degradation of rubbers and elastomers [19] under conditions of short-term exposure to oily fractions showed that the action of oily fractions is uniform over the entire exposed area. In the present experiment, the distribution of degraded (discolored) areas shows a connection with the distribution of areas identified as infected.

Microscopic observations have shown that the discoloration effect is in fact the result of the presence of microcracks in the topcoat (Figure $6 \mathrm{~b}$ ). The density of the micro-crack mesh increased with the time of exposure. The potential cause of the developing degradation process is a chemical attack of microbial metabolic products. Fungi of the genera Penicillium, Aspergillus, Alternaria, and Acremonium are considered the most probable [52,53]. The possible presence of $\mathrm{NH}_{3}$ and $\mathrm{H}_{2} \mathrm{~S}$ (as aggressive factors) in the metabolic products of microorganisms and the reactions stimulated by them is indicated by the authors of publications [54-56]. 


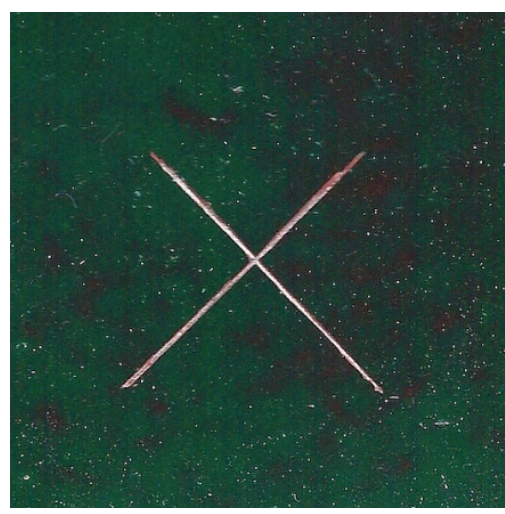

(a) $50 \times 50 \mathrm{~mm}$

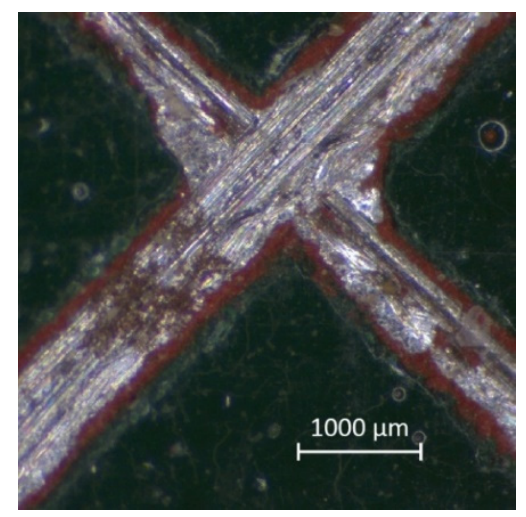

(b) $4 \times 4 \mathrm{~mm}$

Figure 6. Deterioration of the surface layer and corrosion of steel under microbial colonies after 8 weeks of exposition, (a) overview, (b) macroscopic image.

In the areas of paint coating damage, an intensive development of steel substrate corrosion processes was observed (Figure $6 b$ ), more intensive where the area attacked by microorganisms was above the simulated damage of paint film.

Sulfide stress cracking and pitting corrosion are indicated as the main forms of corrosion damage in steels. In the grey cast iron, graphitic corrosion may also occur [56]. The main types of corrosive reactions can be considered:

(a) Multi-step process to form iron sulfides and the following type reactions [56]

$\mathrm{FeS}_{2}+3 \frac{1}{2} \mathrm{O}_{2}+\mathrm{H}_{2} \mathrm{O} \rightarrow \mathrm{FeSO}_{4}+\mathrm{H}_{2} \mathrm{SO}_{4}$

$\mathrm{FeS}_{2}+14 \mathrm{Fe}^{3+}+8 \mathrm{H}_{2} \mathrm{O} \rightarrow 15 \mathrm{Fe}^{2+}+2 \mathrm{SO}_{4}^{2-}+16 \mathrm{H}^{+}$

(b) Possible formation of soluble iron-ammonium complexes.

In specimens with an oily biomass layer on the zinc base a slight degradation of the surface layer was observed (in relation to the double layer). However, in the immediate vicinity of the coating damage a progressive destruction of the zinc layer was observed (Figure 7), indicating the presence of micro-scale electrochemical processes. In locally formed microcells, zinc is the anode, iron is the cathode. Destruction of the zinc coating is stimulated by the formation of a high-proton environment during the reactions described in (a) above. The resulting electrochemical system may significantly affect the hydrogen absorption by steel and the development of hydrogen degradation.

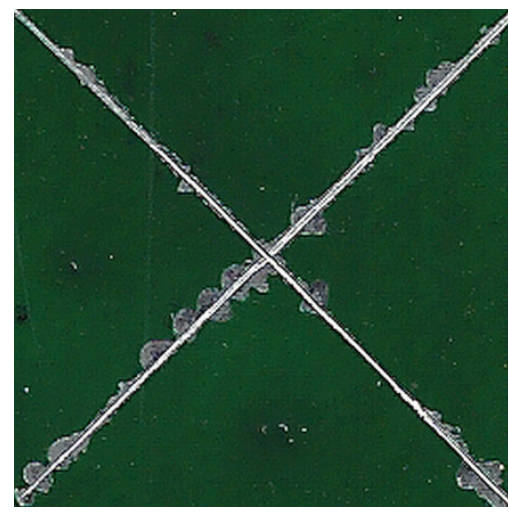

(a) $20 \times 20 \mathrm{~mm}$

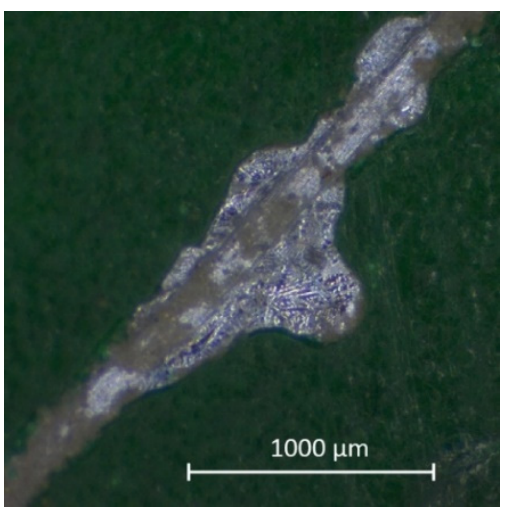

(b) $2 \times 2 \mathrm{~mm}$

Figure 7. Destruction of the zinc layer under bacterial colonies after 8 weeks of exposition, (a) overview, (b) macroscopic image.

No corrosive damage was observed under the layers of wood biomass sediments in experimental conditions. The presence of tannins in the biomass, whose anti-corrosive 
action is known and applied in practice, can be indicated as a potential cause of inhibition of corrosion.

\subsection{SEM/EDS Investigations}

SEM investigations were carried out in areas of discoloration where potential paint film degradation was found. Selected results, obtained after 8 weeks of exposition, are presented in Figure 8. The areas identified during the microscopic examination of degraded areas showed the presence of discontinuity clusters of microfractures (Figure 8a,b) and cavities (Figure 8c-e) forming clusters of mostly elongated shapes (Figure 8f).

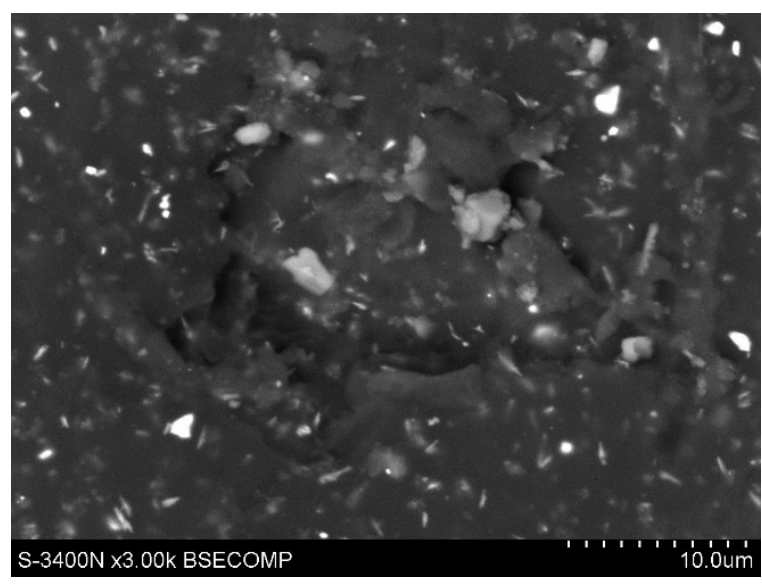

(a)

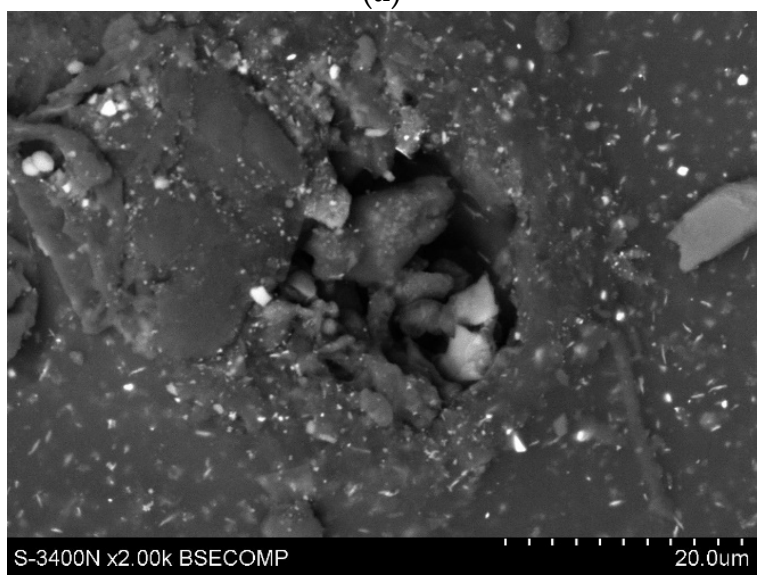

(c)

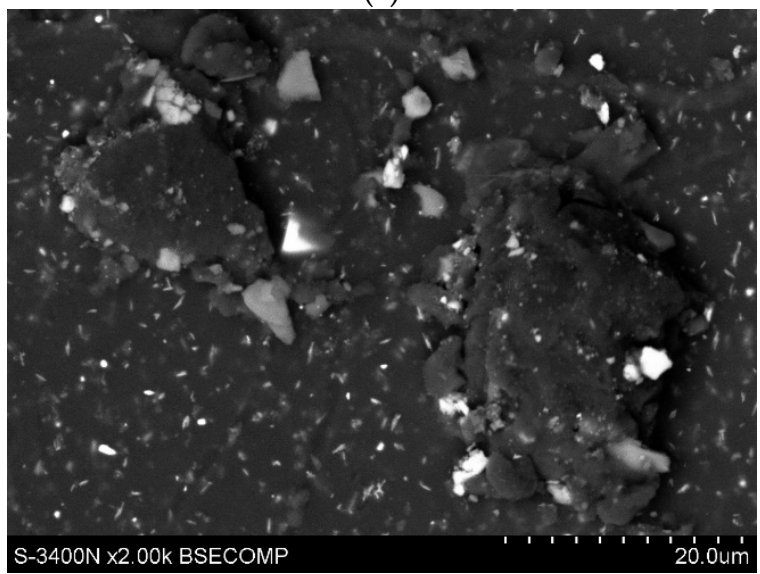

(e)

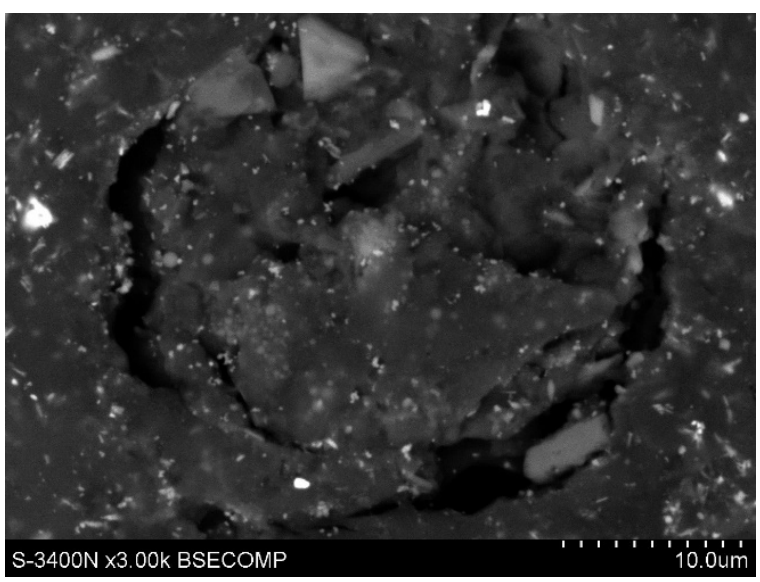

(b)

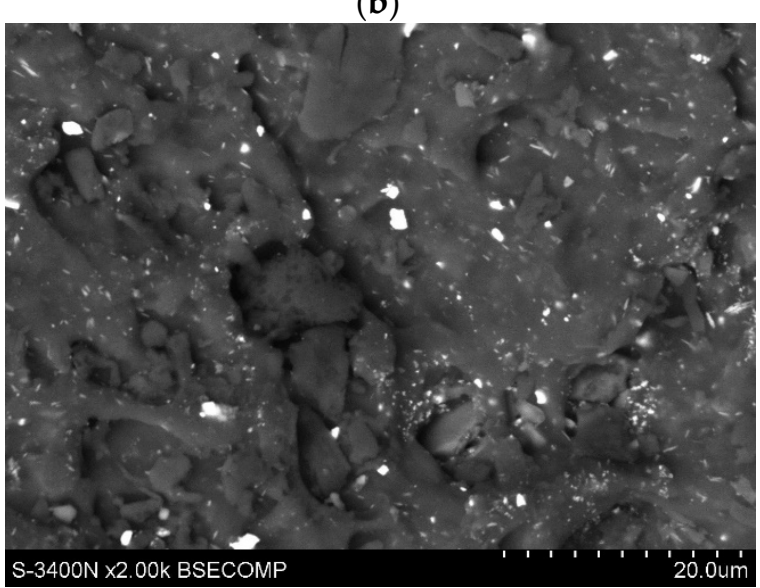

(d)

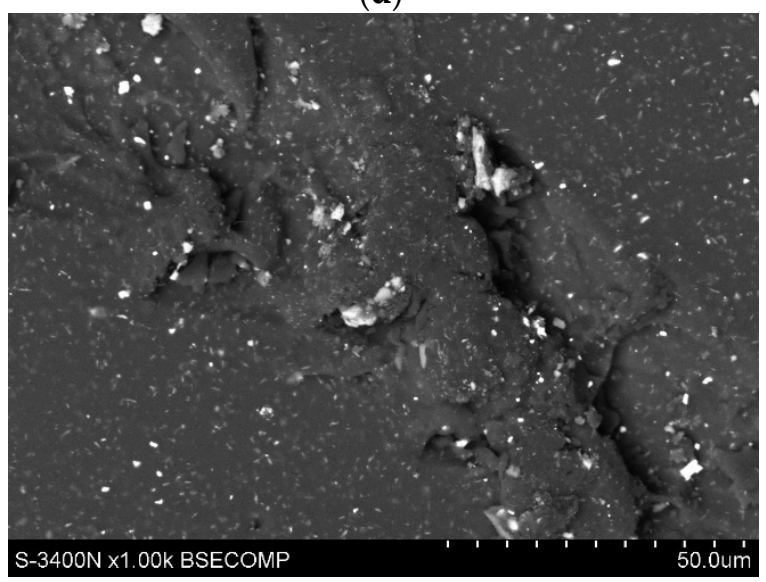

(f)

Figure 8. Selected forms of paint coating degradation in areas of bacterial colony development after 8 weeks of exposition. SEM, clusters of microfractures (a,b); cavities (c-e) and clusters of elongated shapes (f). 
The observed morphology of degradation of coatings and corrosion damage to steel specimens indicates a high probability of pitting corrosion. On the other hand, the presence of an anode zinc layer in the high-proton environment may develop the hydrogen degradation process. Both processes, in combination with dynamic loads and environmental impact, characteristic for cargo handling facilities in sea ports, are conducive to fatigue and fatigue-corrosive destruction $[57,58]$.

An EDS examination was performed in areas identified as infested by microorganisms. An example of the studied area is shown in Figure 9. Several characteristic EDS spectra have been identified, as shown in Figure 10. The spectrum of micro-areas free of attack is shown in Figure 10a. A spectral line of chlorine comes from the base of the paint coating, i.e., chlorinated rubber. The next chart (Figure 10b) shows the presence of spectral lines of elements, the presence of which may result from the contamination of biomass with elements from the storage environment. The third EDS spectrum (Figure 10c) indicates a presence of heavy metals, especially barium, in areas attacked by microorganisms.

The sulfur lines in the spectra in Figure $10 \mathrm{~b}, \mathrm{c}$ are related generally to the presence of amino acids containing sulfur, e.g., methionine and cysteine in rapeseed. The other source of sulfur in rapeseed meal may be glucosinolates. As reported by other authors, the majority of sulfuric compounds (95\%) remained in the rapeseed meal after seed processing. Only a small fraction of sulfuric compounds initially present in seed, contained in amino acids and glucosinolates (less than $0.1 \% \mathrm{~S}$ ) pass into oil $[32,40,59]$. The above authors stated, that these sulfur compounds are significant for corrosion, since production devices, used to the processing of rapeseed corrode more intensively than in the case of other oilseeds.

The presence of sulfur compounds, metabolized by microorganisms, may result in pitting corrosion [60], as well as hydrogen degradation [61].

This presence of heavy metals is the result of the following causal chain:

1. Absorption of barium and other heavy metals from contaminated soil [62].

2. Accumulation of barium and heavy metals in oily plant tissues including Brassicae [63].

3. Relatively easy migration of barium in rapeseed tissues, allowing for a relatively high and even concentration of $20 \mu \mathrm{g} / \mathrm{kg}$ in the whole plant [64].

4. Metabolization of barium compounds by microorganisms, their deposition in sedimentary layers, and transformation of insoluble compounds into soluble ones $[65,66]$.

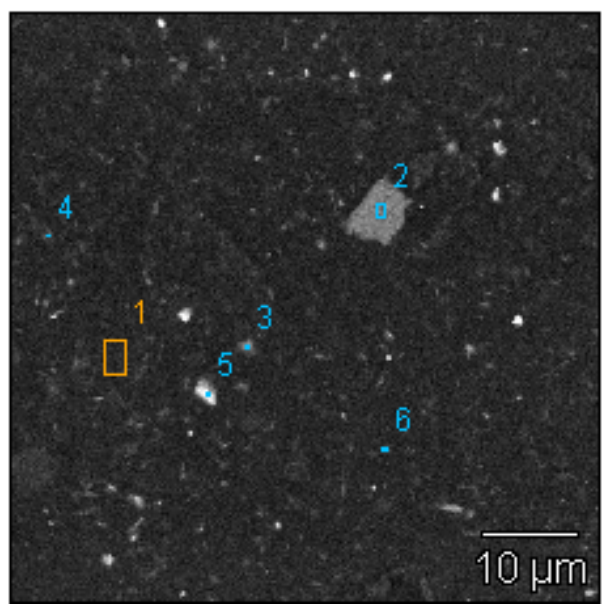

Figure 9. Examples of area selected to EDS examination, point 1: Areas free of attack, 2: Contamination of biomass with elements from the storage environment, 3-6: Areas attacked by microorganisms with barium and other metals presence. 


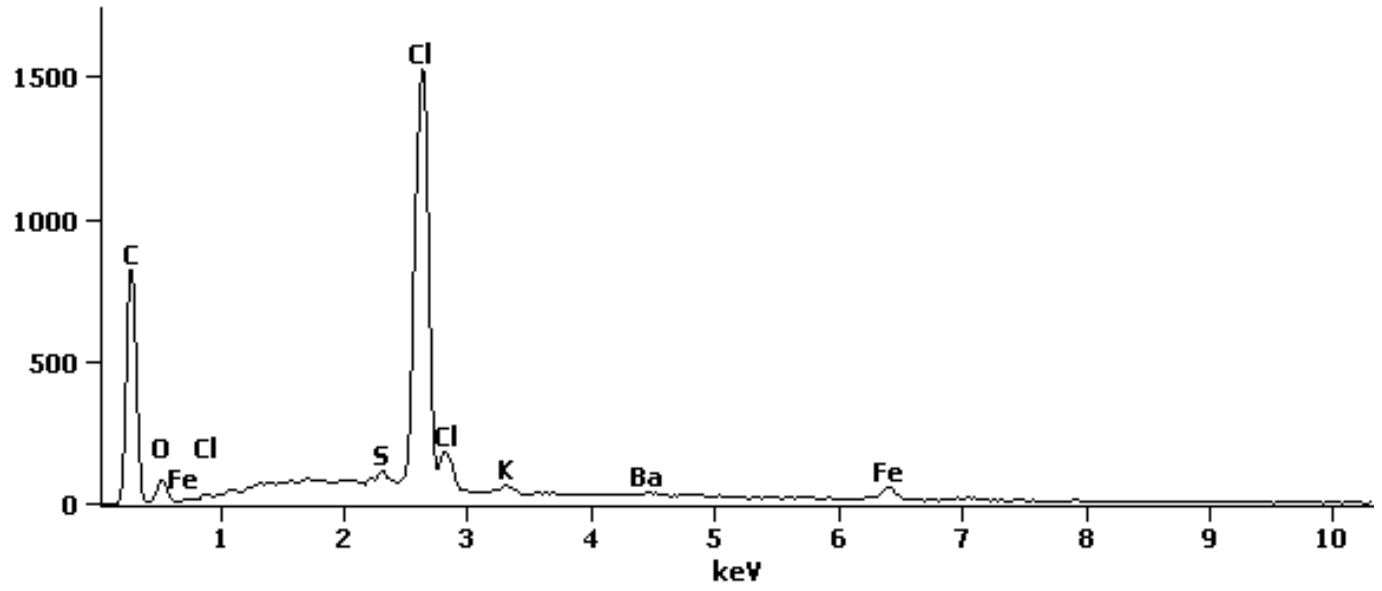

(a)

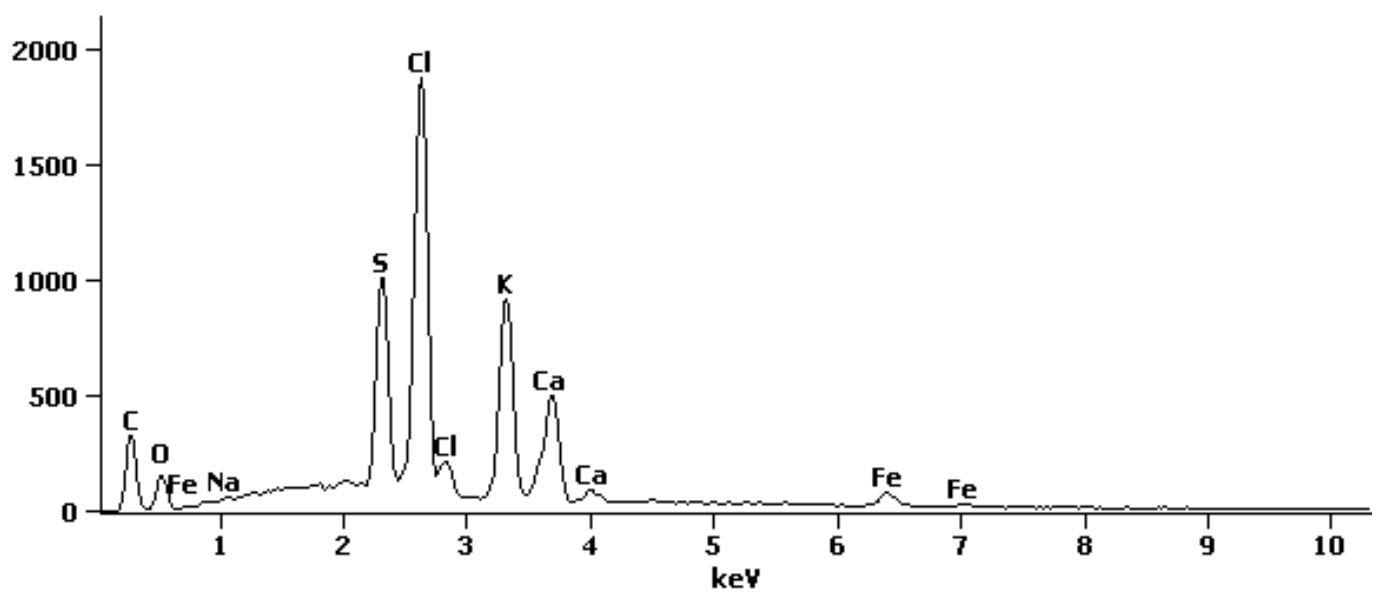

(b)

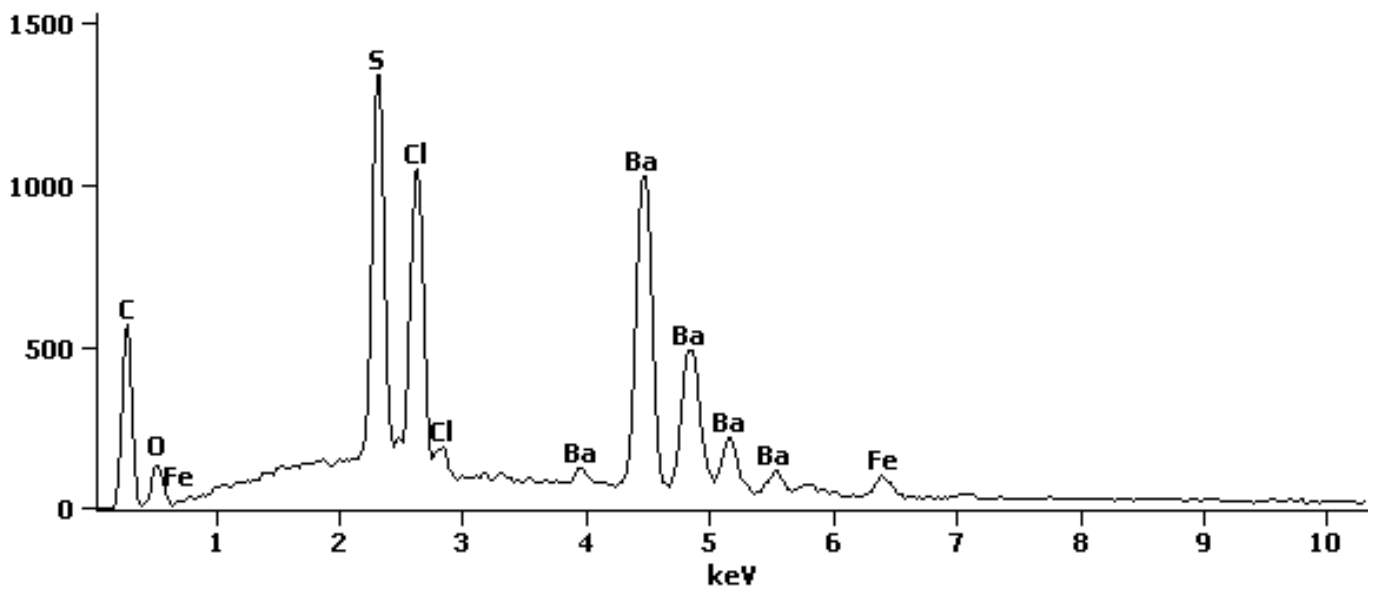

(c)

Figure 10. EDS spectrum energy $[\mathrm{keV}\}$ vs. intensity $[\mathrm{cps} / \mathrm{eV}]$ in areas of bacterial colony development. (a) Point 1 in Figure 9, (b) point 2 in Figure 9, (c) point 3 (and 4,5,6, respectively) in Figure 9.

Waste fractions of oil plants contain fungal spores, which in a relatively short time initiate the growth of colonies. The growth rate of these colonies, measured by the increase in the area they cover in an adopted time interval, can be estimated with sufficient accuracy by using a logistic model. 
Three main categories of damage are observed in areas affected by colonies of microorganisms:

(a) Direct corrosive attack on a metal element resulting from the presence of aggressive metabolic products of micro-organisms, in particular, hydrogen sulphide and barium chlorides;

(b) Development of electrochemical processes resulting in the destruction of zinc coatings;

(c) Degradation of paint coatings, consisting of the formation of a network of microcracks in the topcoat and then the primer.

The presence of Penicillus and Aspergillus fungi is indicated as the most probable under the conditions of the experiment. In real conditions of transshipment of different batches of biomass, microorganisms of other groups are likely to occur, including bacteria directly causing corrosive processes. In this case, the destruction process can be much more rapid due to the presence of synergistic effects.

The obtained results allow, in addition to the basic data, to formulate operational recommendations for the use of the energy biomass handling transport systems. The important information is to identify the accelerated degradation of paint coatings as a potential source of danger. This issue is relatively rarely mentioned in the literature related to the operation of the above mentioned devices. In comparison with publications on the biodegradation of paint coatings $[67,68]$, the results obtained indicate the possibility of accelerated degradation also in relation to the chlorinated rubber paints.

It should be mentioned that the heterogeneity and variability of the composition of the energy biomass batch is a phenomenon known to authors for a long time. This is one of the reasons for court and arbitration proceedings between the recipients and suppliers of biomass. The subject of disputes being the physical properties of biomass, as well as the accelerated wear of some parts of the transport equipment.

\section{Conclusions}

The initial objectives of the presented research were: (a) Assessment of the development of typical forms of corrosion damage under the biomass sediments, (b) identification of other hazards potentially present in the conditions of transshipment of energy biomass, taking into account the specificity of transport of biomass by sea and its transshipment in seaports. This issue has been taken up since the presence of dusty fractions in mass cargoes of plant origin is a source of physicochemical problems. These include: Acceleration of mechanical wear and tear, explosion hazard, and the formation of layers of sediment on the port equipment used to handle cargo. These phenomena are intensified by a relatively high proportion of powdered fractions and the formation of sludge layers stimulated by moisture condensation on elements of the equipment under specific conditions of the port microclimate.

There are three main destructive factors in energy biomass transport systems: (a) Direct corrosive attack on a metal element; (b) development of electrochemical processes; (c) degradation of paint coatings, consisting of the formation of a network of micro-cracks in the topcoat and then the primer. As shown in the experiment, a relatively short period of 2 weeks is sufficient to initiate corrosive processes. In practice, the periods of layering and latent development of corrosion processes can be many times longer in the case of technical port equipment, cranes in particular. After a period of 8 weeks, in addition to the development of typical corrosion processes in unprotected areas, a significant degree of chlorinated rubber paint film degradation was found. Explaining the causes of this degradation has become an additional research objective.

Based on previous own research, literature review, and studies presented in Sections 3.3 and 3.4, a microbiological attack was indicated as the cause of paint film degradation. EDS research and literature analysis also showed that microbiological phenomena are a potential channel for transferring heavy metals to the surface of machine parts. According to the authors, it is a significant phenomenon due to the use of biomass obtained from the reclamation of post-industrial areas for energy purposes. 
The simplifying condition, adopted in the presented studies, was to accept a homogeneous batch of oily biomass, coming directly from the processing plant. This is a limitation in relation to real situations in which batches of biomass may have a heterogeneous composition, and in the transport chain there is a whole range of points in which the infection with bacteria, non-specific for the transported biomass, may occur. On this basis, it is possible to indicate the directions of further research on the phenomena identified in the work: (a) Changes in the chemical composition and bacterial flora of biomass during the transport by sea; (b) changes in the surface condition of the properties of construction materials subjected to degradation processes including fracture mechanics; (c) research on the selection of appropriate protective coatings in energy biomass handling equipment, including resistance to microbiological factors; (d) identification of transport chain nodes where there is the greatest risk of infecting the biomass load with bacteria that cause deterioration processes and methods to minimize such risks.

The research carried out in the present work and potential future research, the directions of which are indicated above, should allow formulating recommendations in the field of maintenance management of means of energy biomass transport. Based on the current observations, it is possible to formulate good operating practices, including the systematic removal of dust layers of plant origin and inspection of the state of anti-corrosion paint coatings in terms of macroscopic losses and degradation in the form of micro-cracks in the coating. Failure to comply with the above conditions may result in an accelerated development of latent damage, which may lead to catastrophic failure.

Author Contributions: Conceptualization, J.C., M.B., and M.S.; methodology, J.C., M.B., and M.S.; validation, J.C., M.B., and M.S.; formal analysis, J.C. and M.S.; investigation, J.G., J.H., and B.C.; writing-original draft preparation, M.B., J.C., and B.C.; writing-review and editing, J.C., M.B., and M.S.; supervision, J.C. and M.S.; funding acquisition, J.C. All authors have read and agreed to the published version of the manuscript.

Funding: This research was funded by the Maritime University of Szczecin, grant number 3/S/I IT / 08 "Interactions and feedback between cargo and means of transport"; grant number 5/S/IIT/2014 "Brittle cracking stimulated by environmental influences in the processes of use of means of transport and infrastructure", and grant "Life cycle management of means of transport and infrastructure facilities".

Institutional Review Board Statement: Not applicable.

Informed Consent Statement: Not applicable.

Acknowledgments: We thank Lech Dorobczyński (Maritime University of Szczecin, Mechatronics and Electrical Engineering Faculty) for verifying the numerical models used in the article.

Conflicts of Interest: The authors declare no conflict of interest.

\section{References}

1. Review of Marine Transport 2016. United Nations Conference on Trade and Development UNTCAD, New York and Geneva. 2016. Available online: https://unctad.org/system/files/official-document/rmt2016_en.pdf (accessed on 11 July 2018).

2. Oilseeds: World Markets and Trade, United States Department of Agriculture, Foreign Agricultural Service. June 2015. Available online: https: / / www.fas.usda.gov/data/oilseeds-world-markets-and-trade (accessed on 12 July 2018).

3. Verein der Kohlenimporteure, Jahresbericht 2018. Available online: www.kohlenimporteure.de (accessed on 10 September 2019).

4. Transport Volume of Iron Ore in Global Seaborne Trade from 2009 to 2019. Available online: http:/ / www.statista.com/statistics/ 264016/global-seaborne-trade-of-iron-ore-since-1985 (accessed on 20 February 2020).

5. Chmiel, J.; Szyszko, M.; Kaczmarek, K.; Pańcyk, K. The Identification of Selected Issues of Port Facilities Wear in Dusty Environments of Bulk Cargoes. Solid State Phenom. 2016, 252, 31-40. [CrossRef]

6. Man, C.K.; Harris, M.L. Participation of large particles in coal dust explosions. J. Loss Prev. Process Ind. 2014, 27, 49-54. [CrossRef]

7. Rout, T.K.; Masto, R.E.; Padhy, P.K.; George, J.; Ram, L.C.; Maity, S. Dust fall and elemental flux in a coal mining area. J. Geochem. Explor. 2014, 144, 443-455. [CrossRef]

8. Křibek, B.; De Vivo, B.; Davies, T. Impacts of mining and mineral processing on the environment and human health in Africa. J. Geochem. Explor. 2014, 144, 387-390. [CrossRef] 
9. Xi, Z.; Jiang, M.; Sun, C.; Tu, X. Controlling the coal dust at transshipment point: A study of the foam-sol foaming device. Int. J. Min. Sci. Technol. 2014, 24, 625-630. [CrossRef]

10. Xie, Y.-S.; Fan, G.-X.; Dai, J.; Song, X. New Respirable Dust Suppression Systems for Coal Mines. J. China Univ. Min. Technol. 2007, 17, 321-325. [CrossRef]

11. Chapman, J.S.; Ruckley, V.A. Microanalysis of lesions and lymph nodes from coalminers' lungs. Br. J. Ind. Med. 1985, 42, 551-555. [CrossRef]

12. Kissell, F.N. (Ed.) Handbook for Dust Control in Mining; US Department for Health and Human Services, Centers for Disease Control and Prevention, National Institute for Occupational Safety and Health: Pittsburgh, PA, USA, 2003.

13. Bojanowska, M.; Chmiel, J.; Pańcyk, K. The Role of Dust Fractions of Rapeseed Meal in the Wear of Cargo Handling System. Solid State Phenom. 2016, 252, 21-30. [CrossRef]

14. Bojanowska, M.; Leśmian-Kordas, R. Wybuchowość pyłów śruty rzepakowej (Explosiveness of rapeseed meal dust). Towarozn. Probl. Jakości 2009, 1, 102-115. (In Polish)

15. Nifuku, M.; Enomoto, H. Evaluation of the explosibility of malt grain dust based on static electrification during pneumatic transportation. J. Loss Prev. Process Ind. 2001, 14, 509-514. [CrossRef]

16. Abbasi, T.; Abbasi, S.A. Dust explosion-Cases, causes, consequences and control. J. Hazard. Mater. 2007, 140, 7-44. [CrossRef] [PubMed]

17. Ramírez, Á.; García-Torrent, J.; Aguado, P.J. Determination of parameters used to prevent ignition of stored materials and to protect against explosions in food industries. J. Hazard. Mater. 2009, 168, 115-120. [CrossRef] [PubMed]

18. Sturaro, A.; Rella, R.; Parvoli, G.; Ferrara, D.; Doretti, L. Chemical evidence and risks associated with soybean and rapeseed meal fermentation. Chemosphere 2003, 52, 1259-1262. [CrossRef]

19. Chmiel, J.; Drzewieniecka, B.; Sokołowska, A.; Przybylak, P. Problemy zużycia taśm przenośnikowych w transporcie nasion roślin oleistych (The problems of wear of conveyor belts for transport oilseeds). Probl. Eksploat. 2010, 4, 207-214. (In Polish)

20. Chmiel, J.; Śmiechowski, J.; Jasiński, M.; Szyszko, M. Selected Issues of Corrosive-Mechanical Wear in the Port Grain Elevator. Solid State Phenom. 2016, 252, 41-50. [CrossRef]

21. Kasprzycka, A.; Skiba, K.; Tys, J. Influence of storage conditions on microbial quality of rapeseed cake and middlings. Int. Agrophys. 2010, 24, 261-265.

22. Li, P.; Wang, F.; Wu, F.; Wang, J.; Liu, L.; Lai, C. Chemical composition, energy and amino acid digestibility in double-low rapeseed meal fed to growing pigs. J. Anim. Sci. Biotechnol. 2015, 6, 37. [CrossRef]

23. Lomascolo, A.; Uzan-Boukhris, E.; Sigoillot, J.-C.; Fine, F. Rapeseed and sunflower meal: A review on biotechnology status and challenges. Appl. Microbiol. Biotechnol. 2012, 95, 1105-1114. [CrossRef]

24. Dinh Tung, N.; Steinbrecht, D.; Vincent, T. Experimental Investigations of Extracted Rapeseed Combustion Emissions in a Small Scale Stationary Fluidized Bed Combustor. Energies 2009, 2, 57-70. [CrossRef]

25. Tesfaye, F.; Lindberg, D.; Moroz, M.; Hupa, L. Investigation of the K-Mg-Ca Sulfate System as Part of Monitoring Problematic Phase Formations in Renewable-Energy Power Plants. Energies 2020, 13, 5366. [CrossRef]

26. Zhang, J.; Rahman, Z.U.; Wang, X.; Wang, Z.; Li, P.; Wang, Y.; Bate, D.; Zhao, K.; Tan, H. Hot corrosion behaviors of TP347H and HR3C stainless steel with KCl deposit in oxy-biomass combustion. J. Environ. Manag. 2020, 263, 110411. [CrossRef] [PubMed]

27. Shao, Y.; Wang, J.; Preto, F.; Zhu, J.; Xu, C. Ash Deposition in Biomass Combustion or Co-Firing for Power/Heat Generation. Energies 2012, 5, 5171-5189. [CrossRef]

28. Wu, S.; Chen, J.; Peng, D.; Wu, Z.; Li, Q.; Huang, T. Effects of Water Leaching on the Ash Sintering Problems of Wheat Straw. Energies 2019, 12, 387. [CrossRef]

29. Kawahara, Y. An Overview on Corrosion-Resistant Coating Technologies in Biomass/Waste-to-Energy Plants in Recent Decades. Coatings 2016, 6, 34. [CrossRef]

30. Oksa, M.; Metsäjoki, J.; Kärki, J. Corrosion Testing of Thermal Spray Coatings in a Biomass Co-Firing Power Plant. Coatings 2016, 6, 65. [CrossRef]

31. Fernandes, D.M.; Squissato, A.L.; Lima, A.F.; Richter, E.M.; Munoz, R.A.A. Corrosive character of Moringa oleifera Lam biodiesel exposed to carbon steel under simulated storage condition. Renew. Energy 2019, 139, 1263-1271. [CrossRef]

32. Rutkowski, A.; Gwiazda, S.; Krygier, K. Sulfur Compounds Affecting Processing of Rapeseed. J. Am. Oil Chem. Soc. 1982, 59, 7-11. [CrossRef]

33. Venzlaff, H.; Enning, D.; Srinivasan, J.; Mayrhofer, K.J.J.; Hassel, A.W.; Widdel, F.; Stratmann, M. Accelerated cathodic reaction in microbial corrosion of iron due to direct electron uptake by sulfate-reducing bacteria. Corros. Sci. 2013, 66, 88-96. [CrossRef]

34. Ovri, J.E.O.; Okeahialam, S.I.; Onyemaobi, O.O. Microbial Corrosion of Mild and Medium Carbon Steels. J. Eng. Sci. Technol. 2013, 8, 639-653.

35. Salgar-Chaparro, S.J.; Lepkova, K.; Pojtanabuntoeng, T.; Darwin, A.; Machuca, L.L. Nutrient Level Determines Biofilm Characteristics and Subsequent Impact on Microbial Corrosion and Biocide Effectiveness. Appl. Environ. Microbiol. 2020, 86, e02885-19. [CrossRef]

36. Videla, H.A.; Herrera, L.K. Understanding microbial inhibition of corrosion. A comprehensive overview. Int. Biodeter. Biodegrad. 2009, 63, 896-900. [CrossRef]

37. Kip, N.; van Veen, J. The dual role of microbes in corrosion. ISME J. 2015, 9, 542-551. [CrossRef] [PubMed] 
38. Grudzień, J. Wear of Port Means of Transport in Dusty Conditions with Energetic Biomass. Diploma Thesis, Faculty of Engineering and Economics of Transport, Maritime University of Szczecin, Szczecin, Poland, 2017.

39. Halska, J. Wear of Port Handling Equipment in Oilseed Dust Pollination Conditions. Diploma Thesis, Faculty of Engineering and Economics of Transport, Maritime University of Szczecin, Szczecin, Poland, 2017.

40. Lindh, L.A.; Dahlen, J.A.H. Hydrogen Sulfide and Acetaldehyde Discharge from a Rapeseed Extraction Plant. J. Am. Oil Chem. Soc. 1989, 66, 972-973. [CrossRef]

41. Demirbas, A. Sustainable cofiring of biomass with coal. Energy Convers. Manag. 2003, 44, 1465-1479. [CrossRef]

42. Boström, D.; Eriksson, G.; Hedman, H.; Boman, C.; Ôhman, M. Bench-scale fluidized bed combustion of rapeseed meal. In Proceedings of the 16th European Biomass Conference \& Exhibition, Valencia, Spain, 2-6 June 2008; pp. 1380-1385.

43. Tannous, J.; Atoui, A.; El Khoury, A.; Francis, Z.; Oswald, I.P.; Puel, O.; Lteif, R. A study on the physicochemical parameters for Penicillium expansum growth and patulin production: Effect of temperature, pH, and water activity. Food Sci. Nutr. 2015, 611-622. [CrossRef]

44. Teleken, J.T.; da Silva Robazza, W.; de Almeida Gomes, G. Mathematical modeling of microbial growth in milk. Cienc. Tecnol. Aliment. 2011, 31, 891-896. [CrossRef]

45. Huang, L. Optimization of a new mathematical model for bacterial growth. Food Control 2013, 32, 283-288. [CrossRef]

46. Goudar, C.T.; Strevett, K.A. Estimating growth kinetics of Penicillium chrysogenum by nonlinear regression. Biochem. Eng. J. 1998, 1, 191-199. [CrossRef]

47. Rosiak, E.; Kołożyn-Krajewska, D. Modele wzrostu bakterii Pseudomonas w produktach gotowych do spożycia (Growth models of the pseudomonas bacteria in ready-to-eat products). Żywność Nauka Technol. Jakość (Food Sci. Technol. Qual.) 2005, 3, 191-206. (In Polish)

48. Bojanowska, M.; Szoka, M. Hygroscopicity of selected solid biofuels in the aspect of their storage susceptibility. In Directions of Research and Development of Nonfood Products; Salerno-Kochan, R., Wolak, A., Eds.; Polskie Towarzystwo Towaroznawcze: Kraków, Poland, 2017. (In Polish)

49. Bojanowska, M. Changes in chemical composition of rapeseed meal during storage, influencing nutritional value of its protein and lipid fractions. J. Anim. Feed Sci. 2017, 26, 157-164. [CrossRef]

50. Sikorski, Z.E. Chemical reactions in proteins in food systems. In Chemical and Functional Properties of Food Proteins; Sikorski, Z.E., Ed.; CRC Press: Boca Raton, FL, USA, 2001.

51. Buraczewska, L.; Gdala, J.; Wasilewko, J.; Buraczewski, S. Ileal digestibility in pigs of protein and amino acids of heat treated rapeseed feeds as affected by protein associated with the NDF fraction. Oilseed Crops 1998, 19, 175-186. (In Polish)

52. White, N.D.G.; Jayas, D.S. Safe storage conditions and infestation potential of canola meal by fungi and insects. J. Stored Prod. Res. 1989, 25, 105-114. [CrossRef]

53. Korniłłowicz-Kowalska, T.; Szwed, A.; Szwed, G. Charakterystyka mykologiczna nasion rzepaku w zależności od warunków ich przechowywania (Mycological characterization of rape seeds depending on storage). Acta Agroph. 2000, 37, 83-93. (In Polish)

54. Sikorski, Z.E. Białka-budowa i właściwości. In Chemia Żywności: T. 2 Sacharydy, Lipidy i Białka (Chemistry of Food: T.2 Saccharides, Lipids and Proteins), 5th ed.; Sikorski, Z.E., Ed.; WNT: Warszawa, Poland, 2007.

55. Steinka, I. Mikrobiologia Żywności i Materiatów Przemysłowych (Microbiology of Food and Industrial Materials); Wydawnictwo Akademii Morskiej: Gdynia, Poland, 2011; pp. 230-234, 251-255. ISBN 978-83-7421-142-0. (In Polish)

56. Jain, P.C. Microbial Degradation of Grains, Oil Seeds, Textiles, Wood, Corrosion of Metals and Bioleaching of Mineral Ores; Department of Applied Microbiology \& Biotechnology, Dr. Harisingh Gour University: Sagar, India, 2006; pp. 1-37.

57. Pustovoi, V.M.; Reshchenko, I.O. Modeling of the in-service degradation of steels of cargo seaport structures under the laboratory conditions. Mater. Sci. 2013, 48, 561-568. [CrossRef]

58. Balyts'kyi, O.I.; Chmiel, J. Resistance of plate shipbuilding steels to cavitation-erosion and fatigue fracture. Mater. Sci. 2015, 50, 736-739. [CrossRef]

59. Zhao, F.J.; Withers, P.J.A.; Evans, E.J.; Monaghan, J.; Salmon, S.E.; Shewry, P.R.; McGrath, S.P. Sulphur nutrition: An important factor for the quality of wheat and rapeseed. Soil Sci. Plant Nutr. 1997, 43 (Suppl. 1), 1137-1142. [CrossRef]

60. Dec, W.; Mosiałek, M.; Socha, R.P.; Jaworska-Kik, M.; Simka, W.; Michalska, J. The effect of sulphate-reducing bacteria biofilm on passivity and development of pitting on 2205 duplex stainless steel. Electrochim. Acta 2016, 212, 225-236. [CrossRef]

61. Domżalicki, P.; Łunarska, E.; Birn, J. Effect of cathodic polarization and sulfate reducing bacteria on mechanical properties of different steels in synthetic sea water. Mater. Corros. 2007, 58, 413-421. [CrossRef]

62. Rai, P.K.; Lee, S.S.; Zhang, M.; Tsang, Y.F.; Kim, K.-H. Heavy metals in food crops: Health risks, fate, mechanisms, and management. Environ. Int. 2019, 125, 365-385. [CrossRef]

63. Coscione, A.R.; Berton, R.S. Barium extraction potential by mustard, sunflower and castor bean. Sci. Agric. (Piracicaba Braz.) 2009, 66, 59-63. [CrossRef]

64. Kowalska, J.; Stryjewska, E.; Bystrzejewska-Piotrowska, G.; Lewandowski, K.; Tobiasz, M.; Pałdyna, J.; Golimowski, J. Studies of Plants Useful in the Re-Cultivation of Heavy Metals-Contaminated Wasteland-A New Hyperaccumulator of Barium? Pol. J. Environ. Stud. 2012, 21, 401-405.

65. Martinez-Ruiz, F.; Jroundi, F.; Paytan, A.; Guerra-Tschuschke, I.; del Mar Abad, M.; González-Muñoz, M.T. Barium bioaccumulation by bacterial biofilms and implications for Ba cycling and use of Ba proxies. Nat. Commun. 2018, 9, 1619. [CrossRef] [PubMed] 
66. Müller, B. Uptake of Barium from Vermiculite by the Bacterium Pseudomonas fluorescens—New Indications for Barium as a Palaeoproxy. Open Geol. J. 2014, 8, 118-123. [CrossRef]

67. Kurowski, G.; Vogt, O.; Ogonowski, J. Paint-Degrading microorganisms. Tech. Trans. 2017, 12, 81-92. [CrossRef]

68. Ravikumar, H.R.; Rao, S.S.; Karigar, C.S. Biodegradation of paints: A current status. Indian J. Sci. Technol. 2012, 5, 1977-1987. [CrossRef] 